\begin{tabular}{lr}
\hline PRACE NAUKOWE UNIWERSYTETU EKONOMICZNEGO WE WROCEAWIU \\
RESEARCH PAPERS OF WROCLAW UNIVERSITY OF ECONOMICS & nr 496・2017 \\
\hline Zmiana warunkiem sukcesu. Potencjał rozwoju i doskonalenia organizacji & ISSN $1899-3192$ \\
& e-ISSN 2392-0041
\end{tabular}

\title{
Marcin Soniewicki
}

Uniwersytet Ekonomiczny w Poznaniu

e-mail: marcin.soniewicki@ue.poznan.pl

\section{ZNACZENIE WYKORZYSTANIA \\ TECHNOLOGII INFORMATYCZNYCH \\ W PROCESACH ZARZĄDZANIA WIEDZĄ \\ PRZEDSIECBIORSTW BUDOWLANYCH*}

\section{THE IMPORTANCE OF KNOWLEDGE MANAGEMENT SYSTEMS' USE IN CONSTRUCTION COMPANIES}

DOI: $10.15611 / \mathrm{pn} .2017 .496 .11$

JEL Classification: D80, M10, M15, M20, L74.

\begin{abstract}
Streszczenie: Celem artykułu jest zbadanie intensywności wykorzystania technologii informatycznych wspierających procesy zarządzania wiedzą w przedsiębiorstwach budowlanych, a także porównanie poziomu konkurencyjności firm w tej branży, wykorzystujących tego rodzaju systemy z wysoką oraz niską intensywnością. Przeprowadzono analizy statystyczne wyników badania ilościowego na130 przedsiębiorstwach funkcjonujących w branży budowlanej. Wyniki pokazały, że dla firm w tej branży najbardziej istotne są systemy magazynowania danych oraz informatyczne systemy komunikacyjne. Analizy ujawniły również, że poziom konkurencyjności badanych przedsiębiorstw jest wyższy wśród firm intensywnie wykorzystujących badane systemy, a różnice w poziomie konkurencyjności są istotne statystycznie. Technologie informatyczne w zarządzaniu wiedzą nie są prawdopodobnie źródłem ani kluczowym elementem w kształtowaniu przewagi konkurencyjnej przedsiębiorstw budowlanych, lecz wyniki otrzymane w niniejszym artykule wskazują, że ich brak może być znaczącą przeszkodą dla osiągnięcia wysokiego poziomu konkurencyjności przez firmę działającą w tej branży.
\end{abstract}

Słowa kluczowe: zarządzanie wiedzą, przedsiębiorstwa budowlane, technologie informatyczne, systemy zarządzania wiedzą, konkurencyjność.

Summary: The goal of the article is examining the usage of intensity of information technologies supporting knowledge management processes (Knowledge Management Systems) in construction companies, and a comparison of competitiveness level of companies in this industry using this sort of systems with high and low intensity. In this publication 130 construction companies have been examined. The research results have shown that for companies in this industry, apart from basic computer systems, the most important are data storage systems

\footnotetext{
* Artykuł i badanie są wynikiem realizacji projektu badawczego finansowanego przez Narodowe Centrum Nauki, grant nr 2011/03/N/HS4/00429.
} 
and communication systems. The analyses have also shown that companies intensively using examined systems are also more competitive than others and the differences in competitiveness level are statistically significant. It has been observed that such differences are greater among companies with higher employment.

Keywords: knowledge management, construction companies, information technology, knowledge management systems, competitiveness.

\section{Wstęp}

Dzisiejsza gospodarka w wielu opracowaniach nazywana jest gospodarką opartą na wiedzy [Welfe 2007]. Posiadanie właściwej wiedzy we właściwym miejscu i czasie decyduje obecnie w coraz większym stopniu o sukcesach oraz przetrwaniu firmy. Jest to związane z tym, że zasób ten jest dziś najbardziej rzadki i poszukiwany, w przeciwieństwie do kapitału czy pracy [Szyjewski, Nowak, Grabara 2004; Paliszkiewicz 2007]. W efekcie coraz bardziej potrzebne jest istnienie skutecznych procesów w zakresie wiedzy w przedsiębiorstwach i aktywne zarządzanie tym zasobem. Niektórzy autorzy uważają, że tego rodzaju działania są wręcz niezbędne, a nie opcjonalne [Geisler, Wickramasinghe 2009]. W związku z tym można stwierdzić, że zarządzanie wiedzą stanowi narzędzie pozwalające na usprawnienie procesów decyzyjnych zachodzących w przedsiębiorstwie, a także na szybsze podejmowanie decyzji, co w dzisiejszym turbulentnym, a także konkurencyjnym środowisku jest nie do przecenienia [Evans 2005].

Przedsiębiorstwa funkcjonujące $\mathrm{w}$ poszczególnych branżach różnią się między sobą w wielu aspektach. W związku z tym można oczekiwać, że procesy w zakresie wiedzy również nie będą identyczne, i warto analizować firmy operujące w poszczególnych branżach oddzielnie. Niniejsza publikacja koncentruje się na ważnej, lecz stosunkowo rzadko analizowanej w zakresie wiedzy branży - budownictwie. Należy podkreślić, że działania w zakresie wiedzy nie są dla przedsiębiorstwa celem samym w sobie. Oczekiwanym efektem inwestycji w tym zakresie jest wzrost poziomu konkurencyjności podmiotu. Wiedza może się wydawać mało znaczącym elementem w kształtowaniu przewagi konkurencyjnej przedsiębiorstw budowlanych, które koncentrują się na wyrobach materialnych. Jednak wyniki badań literaturowych pokazują, że jest inaczej. Zagadnienie konkurencyjności przedsiębiorstw budowlanych było badane w literaturze, m.in. przez Barbarę Jankowską [2003] oraz Janusza Signetzkiego [2011]. W obu opracowaniach podkreślano rolę czynnika wiedzy jako ważnego elementu w kształtowaniu przewagi konkurencyjnej tego typu przedsiębiorstw.

Zarządzanie wiedzą jest bardzo złożoną i szeroką koncepcją. Jednym z ważnych, wręcz nieodłącznych jej elementów składowych są technologie informatyczne [Dąbrowski, Gierszewska 2005]. Istnieją autorzy, którzy określają je nawet mianem rdzenia koncepcji zarządzania wiedzą [Lee, Kim, Kim 2012], co jest raczej przesadnym twierdzeniem. Jednak zdecydowanie można się zgodzić z opinią, że są one 
jedną z bardziej skutecznych dźwigni $\mathrm{w}$ działaniach związanych z zarządzeniem zasobem wiedzy [Kowalczyk, Nogalski 2007]. Zastosowanie technologii informatycznych znacznie ułatwia, upraszcza i przyspiesza przepływ wiedzy w podmiotach gospodarczych, a także pozwala na łatwe gromadzenie, analizę i wykorzystanie dużych ilości omawianego zasobu [Anantatmula 2008; Busch 2008; Koskinen, Pihlanto 2008].

W polskiej literaturze naukowej nie można odnaleźć wielu analiz w zakresie wykorzystania technologii informatycznych w przedsiębiorstwach budowlanych. Dostępne publikacje koncentrują się na wspomnianym zagadnieniu raczej ogólnie, np. Tomasz Szymański [2013], albo na bardzo wąskim jego elemencie, np. na specyficznym rodzaju oprogramowania, często technicznym - Elżbieta Radziszewska-Zielina [2010] czy Wojciech Bogusz [2008]. Niniejsza publikacja skupia się na określonym obszarze, na danej kategorii systemów - wspierającej procesy zarządzania wiedzą w przedsiębiorstwach. Ponadto artykuł analizuje to zagadnienie w kontekście poziomu konkurencyjności podmiotów. Tego rodzaju badanie nie zostało dotychczas przeprowadzone. Wśród publikacji zagranicznych można odnaleźć zdecydowanie więcej artykułów koncentrujących się zagadnieniu technologii informatycznych wspierających procesy zarządzania wiedzą w przedsiębiorstwach budowlanych, $\mathrm{np}$. Rezugi i in. [2011]; Rezugi [2001]; Björk [2001]; Dave, Koskela [2009]; Hari, Egbu, Kumar [2005] czy Peansupap, Walker [2005]. Pokazuje to lukę badawczą, którą niniejsza publikacja stara się częściowo uzupełnić.

\section{Metodologia}

Źródłem danych wykorzystanych w niniejszym artykule jest ilościowe badanie empiryczne przeprowadzone w roku 2012 oraz na początku 2013 roku (1). Operatem losowania była baza przedsiębiorstw Kompass Poland. Kwestionariusze ankiet do badanych podmiotów wysyłane były drogą elektroniczną, a także pocztą tradycyjną, gdyż nie było możliwości wykonania wysyłki poprzez Internet do wszystkich podmiotów.

Wspomniane badanie zostało wykonane wśród przedsiębiorstw wielu branż. Pozyskano ponad 1200 wypełnionych kwestionariuszy ankiety. Wśród nich wyróżniono 130 firm funkcjonujących w branży budowlanej. Struktura badanej próby w zakresie wielkości analizowanych podmiotów została przedstawiona w tabeli 1.

Tabela 1 pokazuje, że największą grupą w badanej próbie są małe (10-49 pracowników) oraz średnie przedsiębiorstwa (50-249 pracowników). Mikroprzedsiębiorstwa (poniżej 10 pracowników) i duże przedsiębiorstwa (250 pracowników lub więcej) posiadają znacznie mniejsze udziały w próbie.

W niniejszym artykule wykorzystano typologię technologii informatycznych wspomagających zarządzanie wiedzą (tabela 2). Została ona opracowana przez autora we wcześniejszej publikacji, na podstawie wielu źródeł literaturowych, a także była konsultowana z informatykiem [Soniewicki 2015]. 
Tabela 1. Liczba analizowanych w artykule przedsiębiorstw budowlanych określonej wielkości

\begin{tabular}{|c|l|c|c|}
\hline $\mathrm{Nr}$ & \multicolumn{1}{|c|}{ Wielkość przedsiębiorstw } & $\begin{array}{c}\text { Liczba przedsiębiorstw } \\
\text { w próbie }\end{array}$ & Udział w próbie \\
\hline 1 & $\begin{array}{l}\text { Mikroprzedsiębiorstwa } \\
\text { (poniżej 10 pracowników) }\end{array}$ & 18 & $13,8 \%$ \\
\hline 2 & $\begin{array}{l}\text { Małe przedsiębiorstwa } \\
(10-49 \text { pracowników) }\end{array}$ & 54 & $41,5 \%$ \\
\hline 3 & $\begin{array}{l}\text { Średnie przedsiębiorstwa } \\
\text { (50-249 pracowników) }\end{array}$ & 48 & $36,9 \%$ \\
\hline 4 & $\begin{array}{l}\text { Duże przedsiębiorstwa } \\
(250 \text { pracowników lub więcej) }\end{array}$ & 10 & $7,7 \%$ \\
\hline & Suma: & $\mathbf{1 3 0}$ & $\mathbf{1 0 0 \%}$ \\
\hline
\end{tabular}

Źródło: opracowanie własne.

Tabela 2. Typologia technologii informatycznych wykorzystywanych do zarządzania wiedzą

\begin{tabular}{|c|l|}
\hline $\mathrm{Nr}$ & \multicolumn{1}{|c|}{ Rodzaje technologii informatycznych wyróżnionych w artykule } \\
\hline 1 & $\begin{array}{l}\text { Podstawowe technologie informatyczne } \\
\text { (Internet, e-mail, edytory tekstu, arkusze kalkulacyjne) }\end{array}$ \\
\hline 2 & $\begin{array}{l}\text { Systemy magazynowania danych } \\
\text { (np. systemy gromadzące, udostępniające i zarządzające dokumentami oraz innymi danymi, } \\
\text { CRM, hurtownie danych) }\end{array}$ \\
\hline 3 & $\begin{array}{l}\text { Informatyczne systemy komunikacyjne } \\
\text { (np. portale korporacyjne, Intranet, forum firmowe, grupy dyskusyjne) }\end{array}$ \\
\hline 4 & $\begin{array}{l}\text { Systemy współpracy grupowej (groupware/collaboration) } \\
\text { (kompleksowe systemy wspierające wspólną pracę) }\end{array}$ \\
\hline 5 & $\begin{array}{l}\text { Systemy wspierania decyzji, systemy eksperckie } \\
\text { (Business Intelligence, Executive Information Systems) }\end{array}$ \\
\hline
\end{tabular}

Źródło: Soniewicki [2015, s. 73], opracowane na podstawie: [Alavi, Tiwana 2006, s. 113-118; Paliszkiewicz 2007, s. 66; Geisler, Wickramasinghe 2009, s. 13; Gierszewska 2011, s. 180; Jemielniak, Koźmiński 2012, s. 306].

Z uwagi na bardzo dużą liczbę dostępnych programów mających na celu wspomaganie zarządzania wiedzą w budowaniu typologii skoncentrowano się na funkcjonalnościach tego typu oprogramowania. Typologia jest kompromisem pomiędzy szczegółowością a relatywnie wysokim poziomem zrozumiałości dla osób niebędących specjalistami w zakresie technologii informatycznych [Soniewicki 2015, s. 73].

Poziom wykorzystania poszczególnych technologii przez badane firmy był mierzony przy użyciu pięciostopniowej skali Likerta, której poszczególne wartości oznaczały: 1 - nie znam lub nie używamy, 2 - niewielkie wykorzystanie, 3 - przeciętne wykorzystanie, 4 - wysokie wykorzystanie, 5 - bardzo wysokie wykorzystanie. 
Ocena poziomu konkurencyjności przedsiębiorstwa jest zawsze trudnym zadaniem, szczególnie w badaniach ilościowych. Do oceny tej często wykorzystuje się metody księgowe, lecz w literaturze można znaleźć autorów wymieniających wiele ich wad, takich jak nieuwzględnianie wiedzy i wartości niematerialnych przedsiębiorstwa [Barney 2011]. W dobie gospodarki opartej na wiedzy czynniki te są bardzo ważne i nie należy ich pomijać [Soniewicki 2015].

W celu pomiaru poziomu konkurencyjności badanych przedsiębiorstw wykorzystano wskaźnik konkurencyjności, który został stworzony przez Krzysztofa Fonfarę [2007]. Składa się on z czterech czynników, zarówno finansowych, jak i niefinansowych - zysk przedsiębiorstwa ogółem, wartość sprzedaży, stopa zwrotu z nakładów inwestycyjnych, a także udział w rynku. Przedstawione czynniki były oceniane przez respondentów z każdej analizowanej firmy, w odniesieniu do ich najbliższych konkurentów. Podejście to jest spójne z opinią Mariana Goryni [2000, s. 49, 52, 53], który również podkreśla znaczenie uwzględniania konkurentów przedsiębiorstwa w pomiarze jego pozycji konkurencyjnej. Oceny każdego z czynników były dokonywane przez respondentów za pomocą pięciostopniowej skali Likerta, w której poszczególne wartości oznaczają: 1 - znacznie gorszy (od najbliższych konkurentów), 2 - groszy, 3 - praktycznie taki sam, 4 - lepszy, 5 - znacznie lepszy. Ostateczną wartością wskaźnika konkurencyjności jest średnia arytmetyczna czterech przedstawionych elementów [Fonfara 2007].

Istotność statystyczna zaobserwowanych w artykule różnic w poziomie konkurencyjności analizowanych grup przedsiębiorstw budowlanych została zbadana za pomocą testu U Manna-Whitneya. Testy przeprowadzono w programie IBM SPSS [Soniewicki 2015].

\section{Wyniki badań}

Niniejsza sekcja artykułu została podzielona na dwie części. W pierwszej skoncentrowano się na zbadaniu intensywności wykorzystania technologii informatycznych wspomagających zarządzanie wiedzą $\mathrm{w}$ przedsiębiorstwach budowlanych. W drugiej części przeprowadzono serię analiz mających na celu sprawdzenie poziomu konkurencyjności firm budowlanych, wykorzystujących z różną intensywnością technologie informatyczne wspomagające zarządzanie wiedzą.

Pierwsza analiza, zaprezentowana $\mathrm{w}$ tabeli 3 , pokazuje intensywność wykorzystania poszczególnych typów technologii informatycznych w przedsiębiorstwach działających w branży budowlanej.

Tabela 3 pokazuje, że podstawowe technologie informatyczne są wykorzystywane w wysokim stopniu praktycznie przez wszystkie przedsiębiorstwa budowlane $(98,5 \%)$. Systemy magazynowania danych również są wykorzystywane w relatywnie wysokim stopniu, lecz znacznie niższym niż podstawowe technologie informatyczne. Trzeci typ badanych systemów - informatyczne technologie komunikacyjne - także wykorzystuje, w wysokim stopniu, relatywnie dużo badanych przedsię- 
Tabela 3. Intensywność wykorzystania poszczególnych technologii informatycznych wspomagających zarządzanie wiedzą w przedsiębiorstwach budowlanych

\begin{tabular}{|l|c|c|c|c|c|}
\hline \multirow{2}{*}{ Rodzaj technologii } & \multirow{2}{*}{$\begin{array}{c}\text { Intensywność } \\
\text { wykorzystywania }\end{array}$} & \multicolumn{2}{|c|}{$\begin{array}{c}\text { Liczba firm } \\
\text { wykorzystujących } \\
\text { daną technologię } \\
\text { w stopniu }\end{array}$} & \multicolumn{2}{|c|}{$\begin{array}{c}\text { Udział firm } \\
\text { wykorzystujących } \\
\text { daną technologię } \\
\text { w stopniu }\end{array}$} \\
\cline { 3 - 7 } & & $\begin{array}{c}\text { niskim } \\
(<3)\end{array}$ & $\begin{array}{c}\text { wysokim } \\
(\geq 3)\end{array}$ & $\begin{array}{c}\text { niskim } \\
(<3)\end{array}$ & $\begin{array}{c}\text { wysokim } \\
(\geq 3)\end{array}$ \\
\hline $\begin{array}{l}\text { Podstawowe technologie } \\
\text { informatyczne }\end{array}$ & 4,36 & 2 & 128 & $1,5 \%$ & $98,5 \%$ \\
\hline Systemy magazynowania danych & 3,12 & 38 & 92 & $29,2 \%$ & $70,8 \%$ \\
\hline $\begin{array}{l}\text { Informatyczne systemy } \\
\text { komunikacyjne }\end{array}$ & 2,71 & 53 & 77 & $40,8 \%$ & $59,2 \%$ \\
\hline $\begin{array}{l}\text { Systemy współpracy grupowej } \\
\text { (groupware/collaboration) }\end{array}$ & 2,17 & 77 & 53 & $59,2 \%$ & $40,8 \%$ \\
\hline $\begin{array}{l}\text { Systemy wspierania decyzji, } \\
\text { systemy eksperckie }\end{array}$ & 1,68 & 104 & 26 & $80,0 \%$ & $20,0 \%$ \\
\hline
\end{tabular}

Źródło: opracowanie własne.

biorstw $(59,2 \%)$, lecz ogólna intensywność ich wykorzystania w próbie jest znacznie niższa w porównaniu do systemów magazynowania danych i wynosi 2,71. Pozostałe technologie - systemy współpracy grupowej oraz systemy wspierania decyzji i systemy eksperckie - są użytkowane przez firmy budowlane z bardzo niską ogólną intensywnością, odpowiednio 2,17 i 1,68.

Kolejna analiza przedstawia intensywność wykorzystania technologii informatycznych w zarządzaniu wiedzą w przedsiębiorstwach budowlanych różnej wielkości (tabela 4).

Tabela 4. Poziom wykorzystania technologii informatycznych w zarządzaniu wiedzą w przedsiębiorstwach budowlanych określonej wielkości

\begin{tabular}{|l|c|}
\hline \multicolumn{1}{|c|}{ Wielkość przedsiębiorstw } & $\begin{array}{c}\text { Poziom wykorzystania technologii } \\
\text { informatycznych w zarządzaniu wiedzą }\end{array}$ \\
\hline $\begin{array}{l}\text { Mikroprzedsiębiorstwa } \\
\text { (poniżej 10 pracowników) }\end{array}$ & 2,71 \\
\hline $\begin{array}{l}\text { Małe przedsiębiorstwa } \\
\text { (10-49 pracowników) }\end{array}$ & 2,74 \\
\hline $\begin{array}{l}\text { Średnie przedsiębiorstwa } \\
\text { (50-249 pracowników) }\end{array}$ & 2,90 \\
\hline $\begin{array}{l}\text { Duże przedsiębiorstwa } \\
(250 \text { pracowników lub więcej) }\end{array}$ & 2,86 \\
\hline
\end{tabular}

Źródło: opracowanie własne. 
Tabela 4 pokazuje, że w ogólnym poziomie wykorzystania technologii informatycznych w zarządzaniu wiedzą w branży budowlanej pomiędzy poszczególnej wielkości przedsiębiorstwami nie istnieją duże różnice (największa różnica wynosi $0,19)$. Należy również podkreślić, że w badanym aspekcie można zauważyć duże podobieństwa pomiędzy mikro- i małymi przedsiębiorstwami, jak również pomiędzy podmiotami średnimi oraz dużymi. Zaobserwowany wyższy poziom wykorzystywania badanych technologii przez większe przedsiębiorstwa (średnie i duże) prawdopodobnie wynika z większych środków finansowych, jakimi dysponują tego typu organizacje.

Następna analiza, przedstawiona w tabeli 5, koncentruje się na intensywności wykorzystania poszczególnych technologii w przedsiębiorstwach budowlanych różnej wielkości.

Tabela 5. Poziom wykorzystania określonych technologii informatycznych w zarządzaniu wiedzą w przedsiębiorstwach budowlanych określonej wielkości

\begin{tabular}{|l|c|c|c|c|}
\hline \multicolumn{1}{|c|}{ Rodzaj technologii } & $\begin{array}{c}\text { Mikroprzedsię- } \\
\text { biorstwa } \\
\text { (poniżej 10 } \\
\text { pracowników) }\end{array}$ & $\begin{array}{c}\text { Małe } \\
\text { przedsiębiorstwa } \\
(10-49 \\
\text { pracowników) }\end{array}$ & $\begin{array}{c}\text { Średnie } \\
\text { przedsiębiorstwa } \\
(50-249 \\
\text { pracowników) }\end{array}$ & $\begin{array}{c}\text { Duże } \\
\text { przedsiębiorstwa } \\
(250 \text { pracowników } \\
\text { lub więcej) }\end{array}$ \\
\hline $\begin{array}{l}\text { Podstawowe } \\
\text { technologie } \\
\text { informatyczne }\end{array}$ & 4,44 & 4,30 & 4,38 & 4,50 \\
\hline $\begin{array}{l}\text { Systemy } \\
\text { magazynowania } \\
\text { danych }\end{array}$ & 2,94 & 2,94 & 3,21 & 3,90 \\
\hline $\begin{array}{l}\text { Informatyczne systemy } \\
\text { komunikacyjne }\end{array}$ & 2,44 & 2,74 & 2,81 & 2,50 \\
\hline $\begin{array}{l}\text { Systemy współpracy } \\
\text { grupowej } \\
\text { groupware/ } \\
\text { collaboration) }\end{array}$ & 2,17 & 2,15 & 2,29 & 1,70 \\
\hline $\begin{array}{l}\text { Systemy wspierania } \\
\text { decyzji, systemy } \\
\text { eksperckie }\end{array}$ & 1,56 & 1,59 & 1,81 & 1,70 \\
\hline
\end{tabular}

Źródło: opracowanie własne.

Tabela 5 pokazuje, że duże przedsiębiorstwa budowlane wykorzystują bardzo intensywnie podstawowe technologie informatyczne i systemy magazynowania danych, a w niewielkim stopniu bardziej zaawansowane narzędzia. Należy również podkreślić, że systemy magazynowania danych mają dość duże znaczenie dla średniej wielkości przedsiębiorstw. Informatyczne systemy komunikacyjne są wykorzystywane w branży budowlanej najintensywniej przez średnie firmy $(2,81)$, a także małe przedsiębiorstwa $(2,74)$, jednak są to niskie poziomy. W przypadku dwóch 
najbardziej zaawansowanych technologii praktycznie w każdej wielkości przedsiębiorstwach poziom ich wykorzystania jest bardzo niski.

Druga część niniejszej sekcji artykułu skupia się na poziomie konkurencyjności przedsiębiorstw funkcjonujących w branży budowlanej, wykorzystujących z różną intensywnością technologie informatyczne wspomagające procesy zarządzania wiedzą. Pierwsza, najbardziej ogólna analiza we wspomnianym zakresie została przedstawiona w tabeli 6 .

Tabela 6. Intensywność wykorzystywania technologii informatycznych w procesach zarządzania wiedzą a poziom konkurencyjności przedsiębiorstw budowlanych

\begin{tabular}{|l|c|c|c|c|}
\hline $\begin{array}{c}\text { Poziom wykorzystania } \\
\text { technologii informatycznych } \\
\text { w zarządzaniu wiedzą }\end{array}$ & $\begin{array}{c}\text { Wskaźnik } \\
\text { konkurencyjności }\end{array}$ & $\begin{array}{c}\text { Liczba } \\
\text { firm }\end{array}$ & $\begin{array}{c}\text { Różnica } \\
\text { (względem } \\
1 \leq \mathrm{x}<2)\end{array}$ & $\begin{array}{c}\text { p-value } \\
\text { (test U Manna- } \\
\text {-Whitneya) }\end{array}$ \\
\hline $1 \leq \mathrm{x}<2$ & 2,58 & 15 & - & - \\
\hline $2 \leq \mathrm{x}<3$ & 2,97 & 58 & 0,39 & $\mathbf{0 , 0 8 6 *}$ \\
\hline $3 \leq \mathrm{x}<4$ & 3,17 & 47 & 0,59 & $\mathbf{0 , 0 4 2 * *}$ \\
\hline $4 \leq \mathrm{x} \leq 5$ & 3,40 & 10 & 0,82 & $\mathbf{0 , 0 1 6 * *}$ \\
\hline
\end{tabular}

$*<0,1 ; * *<0,05 ; * * *<0,01$.

Źródło: opracowanie własne.

Wyniki analiz zawarte w tabeli 6 pokazują, że im wyższe wykorzystanie analizowanych technologii informatycznych w przedsiębiorstwach budowlanych, tym wyższy poziom ich konkurencyjności. Przedstawione różnice są istotne statystycznie, w większości przypadków przy $\alpha<0,05$. Podmioty z bardzo niskim $(1 \leq \mathrm{x}<2)$ wskaźnikiem wykorzystania analizowanych technologii informatycznych stanowią niewielki udział $(11,5 \%)$ i są one najmniej konkurencyjnymi firmami. Największą grupę tworzą podmioty z relatywnie niskim wykorzystaniem badanych technologii $(2 \leq \mathrm{x}<3)$. Ich poziom konkurencyjności $(2,97)$ jest przeciętny, bo tylko nieznacznie niższy od poziomu 3, który oznacza poziom konkurencyjności porównywalny z najbliższymi konkurentami. Przedsiębiorstwa charakteryzujące się relatywnie wysokim $(3 \leq \mathrm{x}<4)$ wykorzystaniem analizowanych technologii stanowią nieco ponad jedną trzecią analizowanej próby $(36,2 \%)$. Ich poziom konkurencyjności $(3,17)$ oznacza, że podmioty te są bardziej konkurencyjne niż ich najbliżsi konkurenci, lecz różnica ta nie jest duża. Najmniejszą (7,7\%), jednak najbardziej konkurencyjną grupę stanowią firmy $\mathrm{z}$ bardzo wysokim $(4 \leq \mathrm{x} \leq 5)$ wykorzystaniem analizowanych technologii. Ich poziom konkurencyjności w porównaniu z ich najbliższymi konkurentami jest znacząco wyższy $(3,40)$.

Kolejna analiza, przedstawiona $\mathrm{w}$ tabeli 7 , pokazuje poziom konkurencyjności firm budowlanych charakteryzujących się niskim $(<3)$ lub wysokim $(\geq 3)$ poziomem 
wykorzystania poszczególnych technologii informatycznych wspomagających zarządzanie wiedzą w przedsiębiorstwie.

Tabela 7. Intensywność wykorzystywania poszczególnych kategorii technologii informatycznych w procesach zarządzania wiedzą a poziom konkurencyjności przedsiębiorstw budowlanych

\begin{tabular}{|c|c|c|c|c|c|c|}
\hline $\begin{array}{c}\text { Wykorzystanie poszczególnych } \\
\text { technologii }\end{array}$ & Niskie & $<3)$ & Wysokie & $(\geq 3)$ & & \\
\hline Rodzaj technologii & $\begin{array}{l}\text { wskaźnik } \\
\text { konkuren- } \\
\text { cyjności }\end{array}$ & $\begin{array}{l}\text { liczba } \\
\text { firm }\end{array}$ & $\begin{array}{l}\text { wskaźnik } \\
\text { konkuren- } \\
\text { cyjności }\end{array}$ & $\begin{array}{c}\text { Liczba } \\
\text { firm }\end{array}$ & $\begin{array}{l}\text { Różnica } \\
\text { (wys.-nis.) }\end{array}$ & $\begin{array}{c}\text { (test } \\
\text { U Manna- } \\
\text {-Whitneya) }\end{array}$ \\
\hline $\begin{array}{l}\text { Podstawowe technologie } \\
\text { informatyczne }\end{array}$ & 1,88 & 2 & 3,05 & 128 & 1,17 & 0,121 \\
\hline $\begin{array}{l}\text { Systemy magazynowania } \\
\text { danych }\end{array}$ & 2,88 & 38 & 3,09 & 92 & 0,21 & 0,170 \\
\hline $\begin{array}{l}\text { Informatyczne systemy } \\
\text { komunikacyjne }\end{array}$ & 2,85 & 53 & 3,15 & 77 & 0,30 & $0,064 *$ \\
\hline $\begin{array}{l}\text { Systemy współpracy grupowej } \\
\text { (groupware/collaboration) }\end{array}$ & 2,92 & 77 & 3,20 & 53 & 0,28 & $0,083 *$ \\
\hline $\begin{array}{l}\text { Systemy wspierania decyzji, } \\
\text { systemy eksperckie }\end{array}$ & 2,98 & 104 & 3,22 & 26 & 0,24 & 0,298 \\
\hline
\end{tabular}

Źródło: opracowanie własne.

Wyniki przedstawione w tabeli 7 pokazują, że w przypadku wszystkich rodzajów analizowanych technologii informatycznych można zauważyć, iż podmioty wykorzystujące dane systemy w wyższym stopniu są bardziej konkurencyjne. Zaobserwowane różnice $\mathrm{w}$ poziomie konkurencyjności pomiędzy podmiotami wykorzystującymi analizowane technologie $\mathrm{w}$ wysokim i niskim stopniu są znaczące praktycznie w przypadku każdej z nich. Należy jednak zaznaczyć, że nie wszystkie z tych różnic są istotne statystycznie.

W przypadku pierwszego z analizowanych elementów - podstawowych technologii informatycznych - można zaobserwować największe różnice w konkurencyjności pomiędzy podmiotami wykorzystującymi je w wysokim oraz niskim stopniu. Niestety, w jednej z grup (niskie wykorzystanie) znajdują się tylko dwa podmioty, stąd otrzymany wynik nie jest wiarygodny.

Kolejnym $z$ badanych elementów były systemy magazynowania danych. Jak wspomniano wcześniej, bardzo duża część przedsiębiorstw budowlanych wykorzystuje tego rodzaju technologie $(70,8 \%)$. Różnica w poziomie konkurencyjności pomiędzy podmiotami, które stosują analizowane systemy w wysokim i niskim stopniu, jest relatywnie niewielka $(0,21)$ i oscyluje wokół wartości środkowej $(3,00)$, oznaczającej poziom konkurencyjności porównywalny z konkurentami. Ponadto należy podkreślić, że wspomniana różnica nie jest istotna statystycznie. 
Analizy dotyczące kolejnej technologii - informatycznych systemów komunikacyjnych - wykazały, że różnica w poziomie konkurencyjności pomiędzy przedsiębiorstwami wykorzystującymi wspomniane narzędzia w wysokim i niskim stopniu jest dość duża - wynosi 0,30. Różnica ta jest największa wśród badanych technologii oraz - co najważniejsze - istotna statystycznie. Wskaźnik konkurencyjności przedsiębiorstw intensywnie wykorzystujących te technologie wynosi 3,15 , co oznacza, że przedsiębiorstwa są bardziej konkurencyjne niż ich najbliżsi konkurenci, lecz nie jest to wartość wysoka. W przypadku systemów współpracy grupowej wartość wspomnianego wskaźnika jest wyższa $(3,20)$. Różnica pomiędzy podmiotami wykorzystującymi te technologie w wysokim i niskim stopniu jest jednak mniejsza $(0,28)$, choć również istotna statystycznie.

Systemy wspierania decyzji, systemy eksperckie są intensywnie wykorzystywane przez niewielką liczbę przedsiębiorstw budowlanych, lecz w grupie tej znalazły się podmioty najbardziej konkurencyjne. Średnia wartość wskaźnika konkurencyjności dla firm korzystających w wysokim stopniu ze wspomnianych systemów wynosi 3,22. Należy jednak podkreślić, że podmioty wykorzystujące te technologie w niskim stopniu nie są znacząco mniej konkurencyjne od swoich najbliższych konkurentów, gdyż ich wskaźnik konkurencyjności wynosi 2,98. Trzeba jednocześnie zaznaczyć, że różnica w poziomie konkurencyjności obu wspomnianych grup nie jest istotna statystycznie.

Podsumowując wyniki przedstawione w tabeli 7, można stwierdzić, że im bardziej zaawansowane technologie informatyczne są wykorzystywane w wysokim stopniu przez przedsiębiorstwa budowlane, tym poziom konkurencyjności stosujących je podmiotów jest wyższy. W przypadku niskiego poziomu wykorzystania poszczególnych technologii konkurencyjność wszystkich analizowanych grup jest niższa od wartości środkowej $(3,00)$.

Wcześniejsze analizy przedstawione w artykule wskazywały, że w branży budowlanej mikroprzedsiębiorstwa w zakresie wykorzystania badanych technologii są zbliżone do małych firm, a średnie przedsiębiorstwa - do dużych podmiotów. W związku z tym, w ramach następnej analizy, badane przedsiębiorstwa podzielono na dwie grupy: mniejsze podmioty - mikro- i małe przedsiębiorstwa (od 1 do 49 pracowników) oraz większe podmioty - średnie i duże przedsiębiorstwa (50 lub więcej pracowników). Wyniki analizy przedstawiono w tabeli 8.

Wyniki zaprezentowane w tabeli 8 pokazują, że w przypadku większych podmiotów (50 lub więcej pracowników) różnica w poziomie konkurencyjności pomiędzy przedsiębiorstwami wykorzystującymi badane technologie w niskim i w wysokim stopniu jest duża. Należy również podkreślić, że większe przedsiębiorstwa charakteryzują się niższym wskaźnikiem konkurencyjności od mniejszych przedsiębiorstw, gdy wykorzystanie badanych technologii jest niskie. W przypadku wysokiego wykorzystania analizowanych systemów sytuacja jest odwrotna. Tego rodzaju wyniki wskazują na większe znaczenie badanych technologii dla podmiotów zatrudniających 50 pracowników lub więcej. Niestety, w obu przypadkach uzyskane wyniki 
nie są istotne statystycznie. Prawdopodobnie duży wpływ ma na to mniejsza pula badanych jednostek, z uwagi na podział analizowanej grupy na dwie części.

Tabela 8. Intensywność wykorzystywania technologii informatycznych w zarządzaniu wiedzą przedsiębiorstw budowlanych określonej wielkości a poziom ich konkurencyjności

\begin{tabular}{|c|c|c|c|c|c|c|}
\hline $\begin{array}{l}\text { Wykorzystanie technologii } \\
\text { informatycznych } \\
\text { w zarządzaniu wiedzą }\end{array}$ & \multicolumn{2}{|c|}{ Niskie $(<3)$} & \multicolumn{2}{|c|}{ Wysokie $(\geq 3)$} & \multirow{2}{*}{$\begin{array}{l}\text { Różnica } \\
\text { (wys.- } \\
\text { nis.) }\end{array}$} & \multirow{2}{*}{$\begin{array}{c}\text { p-value } \\
\text { (test } \\
\text { U Manna- } \\
\text {-Whitneya) }\end{array}$} \\
\hline $\begin{array}{l}\text { Wielkość } \\
\text { przedsiębiorstw }\end{array}$ & $\begin{array}{l}\text { wskaźnik } \\
\text { konkuren- } \\
\text { cyjności }\end{array}$ & $\begin{array}{l}\text { liczba } \\
\text { firm }\end{array}$ & $\begin{array}{l}\text { wskaźnik } \\
\text { konkuren- } \\
\text { cyjności }\end{array}$ & $\begin{array}{l}\text { liczba } \\
\text { firm }\end{array}$ & & \\
\hline $\begin{array}{l}\text { Mikro oraz małe } \\
\text { przedsiębiorstwa } \\
\text { (1-49 pracowników) }\end{array}$ & 2,93 & 41 & 3,16 & 31 & 0,23 & 0,262 \\
\hline $\begin{array}{l}\text { Średnie oraz duże } \\
\text { przedsiębiorstwa } \\
\text { (50 lub więcej pracowników) }\end{array}$ & 2,84 & 32 & 3,27 & 26 & 0,43 & 0,122 \\
\hline
\end{tabular}

Źródło: opracowanie własne.

Otrzymane interesujące wyniki uzasadniają dalsze, bardziej szczegółowe analizy w zakresie poszczególnych technologii informatycznych (tabela 9). Nie analizowano jednak podstawowych technologii informatycznych, gdyż w badanej grupie znajdowało się za mało przedsiębiorstw, zarówno większych, jak i mniejszych, które wykorzystują te technologie w niskim stopniu.

Wyniki badań zawarte w tabeli 9 wskazują, że dla większych przedsiębiorstw (50 lub więcej pracowników) duże znaczenie mają trzy z czterech analizowanych technologii - systemy magazynowania danych, informatyczne systemy komunikacyjne oraz systemy współpracy grupowej. Różnice w poziomie konkurencyjności wśród tej wielkości przedsiębiorstw, wykorzystujących wyżej wymienione technologie z wysoką i niską intensywnością, są duże, zwłaszcza w porównaniu z mniejszymi podmiotami (1-49 pracowników). Szczególnie duży kontrast w tym względzie pomiędzy dwoma wielkościami podmiotów występuje w przypadku systemów magazynowania danych $(0,09$ i 0,38$)$. Co do systemów wspierania decyzji i systemów eksperckich - różnice w obu badanych grupach są podobne $(0,26$ i 0,23$)$. Należy jednak zaznaczyć, że tego rodzaju systemy są bardzo zaawansowane i specyficzne. Otrzymane wyniki wskazują również, że niewiele spośród badanych przedsiębiorstw wykorzystuje je intensywnie.

Należy podkreślić, że we wszystkich przypadkach (w odniesieniu do każdej technologii), przy niskim wykorzystaniu badanych technologii mniejsze firmy charakteryzują się wyższym poziomem konkurencyjności niż większe podmioty. W przypadku wysokiego poziomu wykorzystania badanych technologii można za- 
Tabela 9. Intensywność wykorzystywania poszczególnych technologii wspomagających zarządzanie wiedzą w przedsiębiorstwach budowlanych określonej wielkości a poziom ich konkurencyjności

\begin{tabular}{|c|c|c|c|c|c|c|}
\hline $\begin{array}{l}\text { Wykorzystanie } \\
\text { poszczególnych }\end{array}$ & \multicolumn{2}{|c|}{ Niskie $(<3)$} & \multicolumn{2}{|c|}{ Wysokie $(\geq 3)$} & \multirow{2}{*}{$\begin{array}{l}\text { Różnica } \\
\text { (wys.- } \\
\text { nis.) }\end{array}$} & \multirow{2}{*}{$\begin{array}{c}\text { p-value } \\
\text { (test } \\
\text { U Manna- } \\
\text {-Whitneya) }\end{array}$} \\
\hline $\begin{array}{l}\text { Wielkość } \\
\text { przedsiębiorstw }\end{array}$ & $\begin{array}{l}\text { wskaźnik } \\
\text { konkuren- } \\
\text { cyjności }\end{array}$ & $\begin{array}{l}\text { liczba } \\
\text { firm }\end{array}$ & $\begin{array}{l}\text { wskaźnik } \\
\text { konkuren- } \\
\text { cyjności }\end{array}$ & $\begin{array}{l}\text { liczba } \\
\text { firm }\end{array}$ & & \\
\hline \multicolumn{7}{|c|}{ Systemy magazynowania danych } \\
\hline $\begin{array}{l}\text { Mikro oraz małe } \\
\text { przedsiębiorstwa } \\
\text { (1-49 pracowników) }\end{array}$ & 2,97 & 23 & 3,06 & 49 & 0,09 & 0,462 \\
\hline $\begin{array}{l}\text { Średnie oraz duże } \\
\text { przedsiębiorstwa } \\
\text { (50 lub więcej pracowników) }\end{array}$ & 2,75 & 15 & 3,13 & 43 & 0,38 & 0,200 \\
\hline \multicolumn{7}{|c|}{ Informatyczne systemy komunikacyjne } \\
\hline $\begin{array}{l}\text { Mikro oraz małe } \\
\text { przedsiębiorstwa } \\
\text { (1-49 pracowników) }\end{array}$ & 2,89 & 30 & 3,13 & 42 & 0,24 & 0,179 \\
\hline $\begin{array}{l}\text { Średnie oraz duże } \\
\text { przedsiębiorstwa } \\
\text { (50 lub więcej pracowników) }\end{array}$ & 2,80 & 23 & 3,18 & 35 & 0,37 & 0,207 \\
\hline \multicolumn{7}{|c|}{ Systemy współpracy grupowej } \\
\hline $\begin{array}{l}\text { Mikro oraz małe } \\
\text { przedsiębiorstwa } \\
\text { (1-49 pracowników) }\end{array}$ & 2,94 & 40 & 3,15 & 32 & 0,21 & 0,279 \\
\hline $\begin{array}{l}\text { Średnie oraz duże } \\
\text { przedsiębiorstwa } \\
\text { (50 lub więcej pracowników) }\end{array}$ & 2,89 & 37 & 3,27 & 21 & 0,38 & 0,191 \\
\hline \multicolumn{7}{|c|}{ Systemy wspierania decyzji i systemy eksperckie } \\
\hline $\begin{array}{l}\text { Mikro oraz małe } \\
\text { przedsiębiorstwa } \\
\text { (1-49 pracowników) }\end{array}$ & 2,99 & 61 & 3,25 & 11 & 0,26 & 0,478 \\
\hline $\begin{array}{l}\text { Średnie oraz duże } \\
\text { przedsiębiorstwa } \\
\text { (50 lub więcej pracowników) }\end{array}$ & 2,97 & 43 & 3,20 & 15 & 0,23 & 0,524 \\
\hline
\end{tabular}

Źródło: opracowanie własne.

uważyć sytuację odwrotną - co do zasady większe przedsiębiorstwa osiągają wyższą konkurencyjność, jednak wyjątek stanowi analiza wykorzystania systemów wspierania decyzji i systemów eksperckich. Niestety, opisane różnice nie są istotne sta- 
tystycznie, co podobnie jak w poprzedniej sytuacji może być po części związane $\mathrm{z}$ niewielką liczbą przedsiębiorstw w analizowanych grupach.

\section{Zakończenie}

Zaprezentowane w niniejszym artykule analizy wykorzystania technologii informatycznych wspomagających zarządzanie wiedzą wykazały, że przedsiębiorstwa budowlane użytkują intensywnie praktycznie tylko podstawowe technologie informatyczne i systemy magazynowania danych. Informatyczne systemy komunikacyjne są wykorzystywane przez te podmioty z relatywnie przeciętną intensywnością. Pozostałe badane technologie są w małym stopniu stosowane przez przedsiębiorstwa z branży budowlanej. Wyniki badań pokazują również, że ogólna intensywność wykorzystania badanych technologii w mikroprzedsiębiorstwach jest podobna do tej w małych firmach. Intensywność użycia badanych technologii w średnich przedsiębiorstwach jest nieco wyższa i niewiele różni się od tej w dużych firmach.

Kluczowe wnioski niniejszego artykułu są jednak związane z poziomem konkurencyjności podmiotów, funkcjonujących w analizowanej branży, które wykorzystują z różną intensywnością technologie informatyczne wspomagające zarządzanie wiedzą. Najważniejsza z analiz pokazała, że im wyższa ogólna intensywność wykorzystania technologii informatycznych wspomagających zarządzanie wiedzą w przedsiębiorstwach budowlanych, tym wyższy poziom ich konkurencyjności. Wszystkie zauważone różnice w tym zakresie pomiędzy badanymi podmiotami okazały się istotne statystycznie. Ponadto firmy budowlane charakteryzujące się najwyższym poziomem $(\geq 4)$ intensywności wykorzystania badanych technologii okazały się dużo bardziej konkurencyjne od swoich najbliższych konkurentów. Bardziej szczegółowe analizy dotyczące określonych technologii pokazały, że w przypadku każdej z nich przedsiębiorstwa wykorzystujące badane systemy w wyższym stopniu są bardziej konkurencyjne. Jednak w tej analizie różnice w poziomie konkurencyjności były mniejsze niż w przypadku analiz wszystkich technologii razem wziętych i nie zawsze istotne statystycznie.

Analizy wskazują również, że wykorzystanie technologii informatycznych w zarządzaniu wiedzą ma większe znaczenie dla średnich (50-249 pracowników) i dużych (250 pracowników lub więcej) przedsiębiorstw budowlanych niż dla mikro- (poniżej 10 pracowników) oraz małych (10-49 pracowników) przedsiębiorstw budowlanych. W przypadku średnich i dużych firm, praktycznie we wszystkich analizach, różnice w konkurencyjności pomiędzy przedsiębiorstwami wykorzystującymi wszystkie oraz poszczególne badane technologie w wysokim i niskim stopniu były większe. Jedyny wyjątek stanowiły najbardziej zaawansowane technologie - systemy wspierania decyzji oraz systemy eksperckie.

Technologie informatyczne nie są prawdopodobnie kluczowym elementem w budowaniu przewagi konkurencyjnej przedsiębiorstwa funkcjonującego w branży budowlanej, lecz wiele analiz przedstawionych w artykule wskazuje, że podmio- 
ty wykorzystujące je w niskim stopniu praktycznie we wszystkich badanych sytuacjach są mniej konkurencyjne niż ich najbliżsi konkurenci. Może to oznaczać, że brak intensywnego wykorzystania omawianych systemów może być przeszkodą w uzyskaniu przewagi konkurencyjnej przez przedsiębiorstwo działające w branży budowlanej.

\section{Literatura}

Alavi M., Tiwana A., 2006, Knowledge Management: The Information Technology Dimension, [w:] Easterby-Smith M., Lyles M.A., 2006, The Blackwell Handbook of Organizational Learning and Knowledge Management, Blackwell Publishing, Oxford, s. 104-120.

Anantatmula V.S., 2008, Knowledge Management Success: Roles of Management and Leadership, [w:] K. O'Sullivan 2008, Strategic Knowledge Management in Multinational Organizations, IGI Global, London, s. 299-310.

Barney J.B., 2011, Gaining and Sustaining Competitive Advantage, Pearson Education, New Jersey. Björk C.-Ch., 2001, Document Management - a key IT technology for the construction industry, Information and Communications Technology in the Practice of Building and Civil Engineering, Proceedings of the 2nd worldwide ECCE Symposium, June.

Bogusz W., 2008, Informatyczne systemy wspomagajace analize ryzyka w procesie budowlanym, „Przegląd Naukowy. Inżynieria i Kształtowanie Środowiska”, nr 1, Warszawa.

Busch P., 2008, Tacit Knowledge in Organizational Learning, IGI Publishing, New York.

Dave B., Koskela L., 2009, Collaborative knowledge management - A construction case study, „Automation in Construction", vol. 18, no. 7, November, s. 894-902.

Dąbrowski J., Gierszewska G., 2005, Strategie Przedsiębiorstw a Zarządzanie Wiedza, Wydawnictwo Wyższej Szkoły Przedsiębiorczości i Zarządzania im. Leona Koźmińskiego, Warszawa.

Evans Ch., 2005, Zarzadzanie Wiedza, Polskie Wydawnictwo Ekonomiczne, Warszawa.

Fonfara K., 2007, Zachowanie przedsiębiorstw w procesie internacjonalizacji - próba poszukiwania teorii marketingu międzynarodowego, „Marketing i Rynek”, nr 12.

Geisler E., Wickramasinghe N., 2009, Principles of Knowledge Management. Theory, Practice, and Cases, M.E. Sharpe, London.

Gierszewska G., 2011, Zarzadzanie wiedza w przedsiębiorstwie - modele, podejścia, praktyka, Oficyna Wydawnicza Politechniki Warszawskiej, Warszawa.

Gorynia M., 2000, Luka konkurencyjna w przedsiębiorstwach a przystapienie Polski do Unii Europejskiej, ,Gospodarka Narodowa”, nr 10, s. 48-67.

Hari S., Egbu Ch., Kumar B., 2005, A knowledge capture awareness tool: An empirical study on small and medium enterprises in the construction industry, „Engineering, Construction and Architectural Management", vol. 12, no. 6, s. 533-567.

Jankowska B., 2003, Międzynarodowa konkurencyjność polskiej branży budowlanej, rozprawa doktorska, Wydział Zarządzania, Akademia Ekonomiczna w Poznaniu, Poznań.

Jemielniak D., Koźmiński A.K., 2012, Zarządzanie wiedza, Wolters Kulwer Polska, Warszawa.

Koskinen K.U., Pihlanto P., 2008, Knowledge Management in Project-Based Companies. An Organic Perspective, Palgrave Macmillan, London.

Kowalczyk A., Nogalski B., 2007, Zarzadzanie wiedza. Koncepcja i Narzędzia, Wydawnictwo Difin, Warszawa.

Lee S., Kim B.G., Kim H., 2012, An integrated view of knowledge management for performance, „Journal of Knowledge Management”, vol. 16, no. 2, s. 183-203. 
Paliszkiewicz J.O., 2007, Zarzqdzanie wiedzq w małych i średnich przedsiębiorstwach - koncepcja oceny $i$ modele, Wydawnictwo SGGW, Warszawa.

Peansupap V., Walker D., 2005, Factors affecting ICT diffusion: A case study of three large Australian construction contractors, „Engineering, Construction and Architectural Management”, vol. 12, z. 1, s. 21-37.

Radziszewska-Zielina E., 2010, System informatyczny do zarządzania relacjami partnerskimi przedsiębiorstw budowlanych, „Czasopismo Techniczne - Budownictwo”, z. 19 (4-B).

Rezgui Y., 2001, Review of information and the state of the art of knowledge management practices in the construction industry, „The Knowledge Engineering Review”, vol. 16, no. 3, September, s. 241-254.

Rezgui Y., Boddy S., Wetherill M., Cooper G., 2011, Past, present and future of information and knowledge sharing in the construction industry: Towards semantic service-based e-construction?, „Computer-Aided Design”, vol. 43, no. 5, May, s. 502-515.

Signetzki J., 2011, Relacje partnerskie z klientami a konkurencyjność przedsiębiorstw budowlanych w Polsce, rozprawa doktorska, Wydział Zarządzania, Uniwersytet Ekonomiczny w Poznaniu, Poznań.

Soniewicki M., 2015, The Company's international Competitive Advantage - the Role of Knowledge, Wydawnictwo Difin, Warszawa.

Szyjewski Z., Nowak J.S., Grabara J.K., 2004, Strategie informatyzacji i zarzadzania wiedza, Wydawnictwa Naukowo-Techniczne, Warszawa.

Szymański T., 2013, Systemy informatyczne wspierajace organizacje z sektora budownictwo, „Zarządzanie i Finanse", nr 1, z. 4, s. 543-587.

Welfe W., 2007, Gospodarka oparta na wiedzy, Polskie Wydawnictwo Ekonomiczne, Warszawa. 